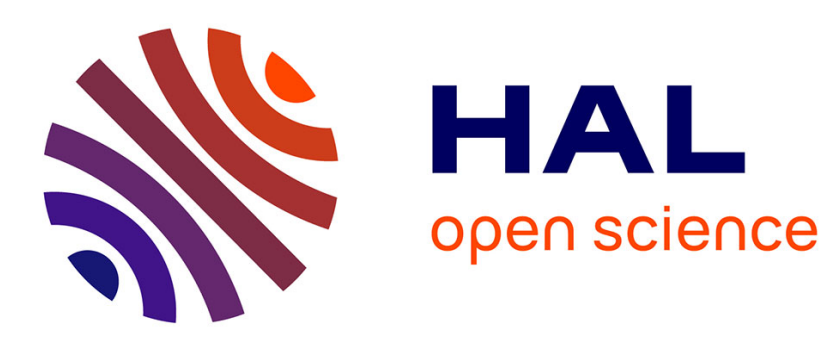

\title{
Research on Virtual Simulation of Flood Propagation in Agricultural Area Under the Land Subsidence
}

\author{
Ping Yu, Shaofei Li, Xu Wang
}

\section{To cite this version:}

Ping Yu, Shaofei Li, Xu Wang. Research on Virtual Simulation of Flood Propagation in Agricultural Area Under the Land Subsidence. 10th International Conference on Computer and Computing Technologies in Agriculture (CCTA), Oct 2016, Dongying, China. pp.360-371, 10.1007/978-3-03006155-5_36. hal-02180011

\section{HAL Id: hal-02180011 \\ https://hal.inria.fr/hal-02180011}

Submitted on 12 Jul 2019

HAL is a multi-disciplinary open access archive for the deposit and dissemination of scientific research documents, whether they are published or not. The documents may come from teaching and research institutions in France or abroad, or from public or private research centers.
L'archive ouverte pluridisciplinaire HAL, est destinée au dépôt et à la diffusion de documents scientifiques de niveau recherche, publiés ou non, émanant des établissements d'enseignement et de recherche français ou étrangers, des laboratoires publics ou privés. 


\title{
Research on Virtual Simulation of Flood Propagation in Agricultural Area under the Land Subsidence
}

\author{
Ping $\mathrm{Yu}^{(\bowtie)}$, Shaofei Li, Xu Wang \\ College of Water Conservancy Engineering, Tianjin Agricultural University, Tianjin, China; \\ yuping200551@163.com
}

\begin{abstract}
Agricultural areas are mainly distributed in the suburbs, however suburs of metropolis are often used as flood storage and detention areas in order to ensure the safety of urban from flood. Severe land subsidence would make a decrease use of flood control facilities like dike and sluice which protect the agricultural areas, and there are important significance to analyze the flood control in agricultural areas affected by double natural disasters. In this paper, the land subsidence observations and sedimentation rate over recent 20 years in Dahuangbao agricultural areas are the object of study, and the flood routing mathematical model is established using the alternating direction implicit method (ADI) with high stability and precision. The results reveal that after comparing the flood values with different return periods between before and after land subsidence, the inundated area and capacity after land subsidence increases, which directly affects the safety of agricultural areas.
\end{abstract}

Keywords: land subsidence; agricultural areas; detention basins; flood routing; alternating direction implicit method

\section{Introduction}

Agricultural areas are mainly distributed in the suburbs, however suburs of metropolis are often used as flood storage and detention areas in order to ensure the safety of urban from flood. Ground subsidence is one of the most important geological disaster in China's coastal areas, Severe land subsidence would make a decrease of flood control facilities like dike and sluice which protect the agricultural areas, not only results in reducing its flood control standards and utility, but also reduced the flood discharge capacity of river channel and affects the security of flood control system. At the present, Impact of domestic and foreign scholars on the flood-control system of land subsidence research mainly focuses on the problems of settlement on the river's discharge ability, flood control and scheduling ${ }^{[1]}{ }^{[2]}$, but the study about flood control safety of the flood storage and detention basins is almost blank. However the flood storage and detention basins is the important part of the river-flood control system and it's also an effective measure for ensuring safety of flood control system and disaster mitigation. So it is significant to study on the impact of settlement on flood control safety of flood storage and detention basins. 
In order to analyze the influence of settlement on the flood storage and detention basins, we must establish the flood routing mathematical model. So far, Domestic and foreign experts have done numbers of research on flood routing simulation. They simulate flood routing with the finite difference method, finite element method and the finite volume method respectively. Italian calleffi and valiani simulated the flood routing of Toce River with two-dimensional shallow water equations ${ }^{[3]}$. In 1991, Liu Shukun did the flood routing simulation of Xiaoqing River with structured grid ${ }^{[4]}$. In 1996, Zhou Xiaode did the flood routing simulation calculation with two-dimensional implicit finite difference model ${ }^{[5]}$. In 2001, Cao Zhifang, Li Yitian simulated flood river bed in flood storage and detention basins with the upwind discrete equations of finite-difference method ${ }^{[6]}$. In 2009, Li Daming used the finite volume method to simulate flooding process in flood storage and detention basin ${ }^{[7]}$. However, these studies are mainly based on the all areas simultaneous application type of flood storage and detention area. It has better suitability for more complicated partition application type of flood storage and detention area to establish the flood routing mathematical model using the alternating direction implicit method (ADI) with high stability and precision.

Comparing the terrain material in different period, analyzing the land subsidence situation from 1985-2008 of Dahuangbao detention basin, and using the flood routing mathematical model based on the alternating direction implicit method, analyzing the flood control safety of Dahuangbao detention basin after land subsided by simulation of flood process based on different criteria.

\section{Land subsidence analysis}

\subsection{The general situation of study area}

Tianjin Dahuangbao detention basin is located in Tianjin Wuqing, Baodi and Ninghe district areas, located in the main flood rump of the north canal between the middle and lower reaches of Qinglongwanjian River and the drainage river of Beijing. Dahuangbao experienced the detain using several times since 1949 such in $1954,1956,1958,1962,1964,1984$ and also contribute significantly to the flood control of Tianjin. Dahuangbao detention basin has 5 partitions, the partition I and II regard left embankment of Liuhe main canal as cofferdam; partition I and III regard north levee of Yan Du drain as cofferdam; partition III and IV regard the north levee of sewage drain as cofferdam; partition I and V regard Daer road as cofferdam. Dahuangbao detention basin's position is shown in Figure 1 


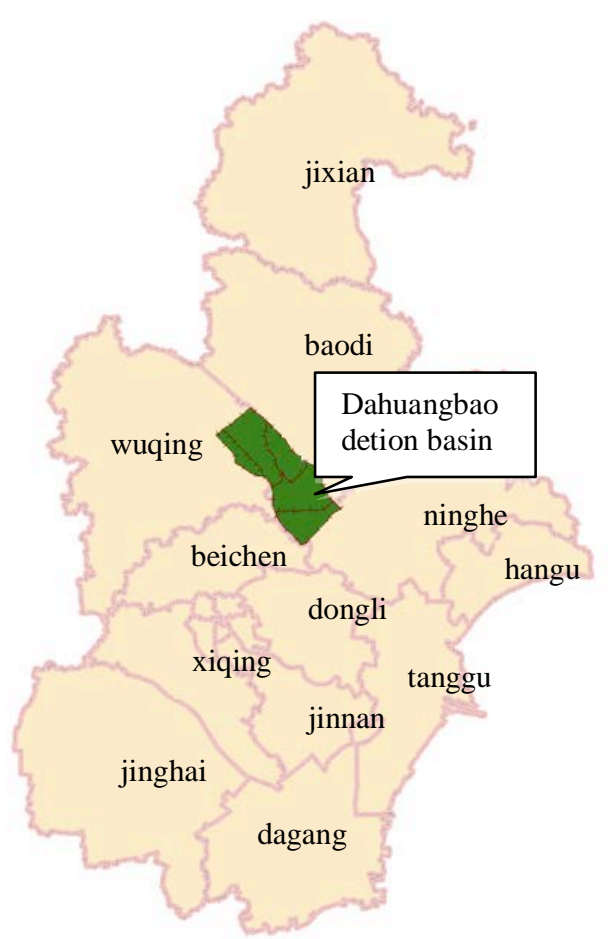

Fig.1. Location of Dahuangbao detention basin

\subsection{Land subsidence analysis}

Since twentieth Century 60 years, the coastal low-lying plain city Tianjin is formed by the active faults and the joint effect of the sea (Bohai), river (the Yellow River and the Haihe River), the settlement which caused by many-sided influence factors such as the over exploitation of groundwater, the tectonic movement and sea level rising, has become one of the main environmental geological problems ${ }^{[8][9]}$. Among these factors, the main factor is the over exploitation of groundwater due to lack of water, so Tianjin is a typical city which occurred ground subsidence because of resource shortage.

In order to reduce the amount of groundwater mining and make the land subsidence velocity tends to be gentle; Tianjin started to implement the control measure of land subsidence in 1985. Based on years of cumulative settlement quantity for annual average settlement volume can be obtained: Baodi, Ninghe, Wuqing, Dongli and Tanggu all or most of the regional average annual settlement amount is less than $35 \mathrm{~mm}$, Jinnan, Xiqing, Hangu, Beichen, the average annual precipitation is greater than $35 \mathrm{~mm}$, the local average annual settlement amount is greater than $70 \mathrm{~mm}$.

Dahuangbao detention basin is located in the junction among Wuqing, Ninghe and Baodi, although the average settlement is less than $35 \mathrm{~mm}$ in Tianjin city, but in the region for many years without storing flood, in recent years, rapid population growth, rapid economic development, people in order to meet the needs of the development to 
over extract the groundwater, result in the land subsidence range expanding and cumulative settlement increasing. In order to analyze the ground subsidence situation of Dahuangbao flood storage and detention basin, we collect topographic map which measured in 1985 and 2008. Through the analysis of the ground settlement and the spatial distribution characteristics can be obtained: from 1985 to 2008 this 23 years, the Cumulative settlement amount of Dahuangbao is between $0 \sim 1500 \mathrm{~mm}$, the average value is $288 \mathrm{~mm}$; the settlement rate is between $0 \sim 65 \mathrm{~mm} / \mathrm{a}$, the average value is $13 \mathrm{~mm} / \mathrm{a}$. The whole area almost occurred settlement, the area of cumulative settlement between the $0 \sim 500 \mathrm{~mm}$ is the largest, $251.8 \mathrm{~km}^{2}$, occupy $87.1 \%$ of the whole settlement area; the area of cumulative settlement between $500 \sim 700 \mathrm{~mm}$ is $23.8 \mathrm{~km}^{2}$, occupy $8.2 \%$ of the whole settlement area. After comparing and analyzing, this result coincides with the 1985 2008 cumulative ground settlement distribution data of Tianjin ${ }^{[10]}$.

\subsection{Settlement analysis of cofferdam project}

Dahuangbao peripheral dyke consist of Kuangergang north levee, Huangsha River left levee, Beijing Drainage River left levee, Jinyu road, Qinglongwan old way right levee and Qinglongwanjian river right levee. We collected the measured results about 1992 and 2009. Comparing the result can be obtained that the maximum settlement amount is $0.51 \mathrm{~m}$, average settlement amount is $0.336 \mathrm{~m}$, an annual settlement is $0.021 \mathrm{~m}$.

According to measuring data of 2009, the crest elevation of Qinglongwan old way levee is $2-5 \mathrm{~m}$, it almost has no levee near the north of Gaozhuanghu village about $5 \mathrm{~km}$, the ground elevation is around $3.0 \mathrm{~m}$. The crest elevation of Huangshahe left levee is $2-3 \mathrm{~m}$, the crest elevation of Kuangergang north levee is around $5 \mathrm{~m}$. Jinyu road belongs to highway bureau, the ground elevation of it is between $3.0-3.5 \mathrm{~m}$. The cofferdam length of Dahuangbao detention basin' s partition is $46.4 \mathrm{~km}$, the partition I and partition $V^{\prime}$ s cofferdam is Daer road, the ground elevation is $3.1-4.7 \mathrm{~m}$; the partition I and partition II' $\mathrm{s}$ cofferdam is left levee of Liuhe main canal, the levee crest elevation is $1.7-2.7 \mathrm{~m}$. The dividing line of partition I and partition III is north levee of Yandu drain; the cofferdam of partition III and partition V is Jiuyuan road and Daer road. The levee crest elevation of Daer road is 3.2-4.8m; the cofferdam of partition III and partition IV is north levee of sewage drain, the current levee crest elevation is $1.6-4.0 \mathrm{~m}$.

\subsection{Settlement comprehensive analysis}

Tianjin city has taken various measures to control the land subsidence, in this condition, the land subsidence rate of Dahuangbao area has slowed further. Considering a variety of factors, combining statistical analysis of settlement, the land subsidence rate is about $0.013 \mathrm{~m}$ per year. The settlement rate of levee is faster than the ground average value; it is around $0.021 \mathrm{~m}$ per year. 


\section{Establishment of flood routing model}

\subsection{Basic principles of model}

Model which based on the Navier-Stokes equations, make the coordinate of discrete solution with alternating direction method (ADI), definite solution condition of the method are as follows.

1) Initial condition

In this 2-dimentional numerical simulation of the main riverbed of detention basin mentioned in this paper, the initial condition is main riverbed generally, namely the initial water level is the surface elevation of grid. The initial condition can be given based on measured data in the water area.

2) Inlet and outlet boundary conditions

The boundary of calculated field is divided into two major categories of open boundary and close boundary. The open boundary is the part which refers to the water exchange with the external part in calculated field, satisfy:

$$
\begin{aligned}
& \partial \overrightarrow{\mathrm{U}} \times \overrightarrow{\mathbf{n}} / \partial \mathrm{n}=0 \\
& \mathrm{q}=\mathrm{q}(\mathrm{t}) \square \mathrm{z}=\mathrm{z}(\mathrm{t})
\end{aligned}
$$

$\mathbf{q}(\mathbf{t})$ is the actual measured flow procedure, $\mathbf{z}(\mathrm{t})$ is the actual measured water level.

For the water grid, boundary conditions give the discharge process; the boundary of back water grid gives the water level process. Close boundary can assume that the normal partial derivative of hydraulic factors is $\partial / \partial \mathbf{n}=\mathbf{O}$ according to the actual situation.

3) The internal boundary condition

In the detention basin, when the flood diversion is needed among construction projects or several flood detention basins, the flow simulation can be described by the formula of weir and sluice hole.

4) Roughness coefficient

When we simulate the flood routing in the flood detention basin, roughness coefficient can be obtained by analyzing the actual measured materials and consulting the planning situation, according to the actual terrain and vegetation in the calculated cells.

\subsection{Solution of the numerical equation}

Numerical method used by model is finite difference method. Due to the difference of time and space form in the actual application, difference method can be divided into explicit, implicit and explicit-implicit alternate methods. Alternating direction implicit method (ADI) is a finite difference schemes using explicit-implicit alternately which is presented by Douqlace and Rachford in 1995, and then it is established by 
Leendertse combined with alternating grid and first applied to the calculation of twodimensional flow field. The ADI method has two kinds of advantages of both explicit and implicit difference scheme, compared with the fully implicit scheme, it needn't require solving a system of algebraic equations, thus requiring less memory, computational complexity are reduced; ADI method is not like explicit scheme appearing fluctuation phenomenon easily in the calculation. Due to explicit and implicit in the alternate use on the axis so that increased amount of errors can be offset. Therefore ADI method has a good numerical stability and accuracy, Physical meaning of the grid as shown in Figure 2, Figure 3, Figure 4.

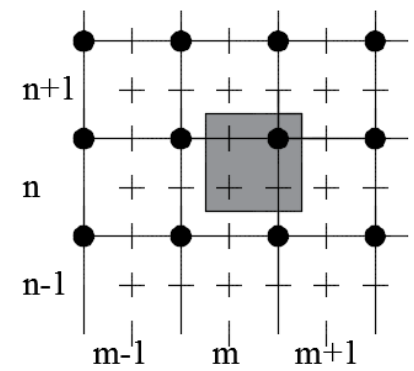

In the Figure:

Fig.2. Definition of the variables in the grids

Full line: calculated grid

Dotted line: interlaced network which has the same coordinates

+: Water level, concentration, salinity and temperature

- : horizontal velocity of axial $\mathrm{x}$

I : horizontal velocity of axial y

- : water level of average depth

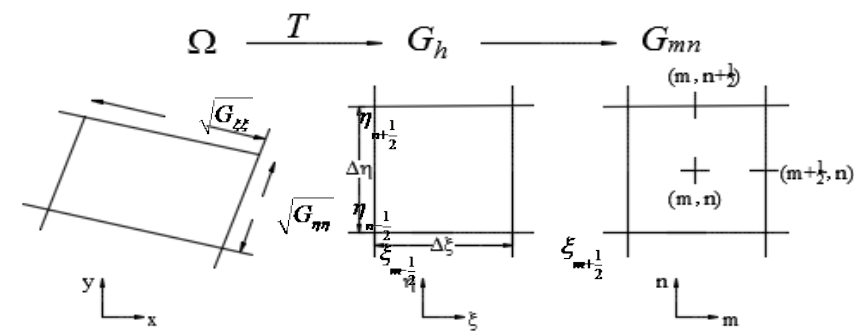

Fig.3. Gener ated by the irregular physical domain diagram of rectangular computational grid
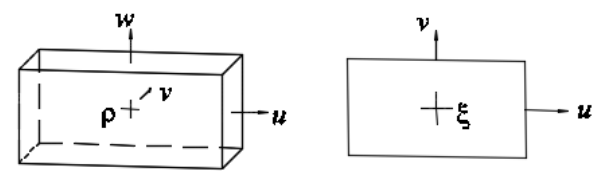

Fig.4. Layout forms of the water level and the velocity in the calculated grids 


\subsection{Division of computational grids}

When the Dahuangbao flood storage detention basin flood, raising up the gate of Langerwo diversion sluice, the flood from Qinglongwanjianhe through the sluice gate, not spread directly, but along the main channel of Langerwoyinhe flows from north to south, after the water flows out of the channel, it spread along the cross-strait gaps on both sides of dike of Langerwoyinhe to both sides. The width of Langerwoyinhe main channel is $30 \mathrm{~m}$, the width of both sides embankment is $200 \mathrm{~m}$, and length is $15 \mathrm{~km}$. In order to simulate the flood flowing situation in intake river and the overflowing situation on both sides, the size of calculated grid must be smaller than the width of main channel. Besides, the amount of diversion gate among the partitions is large and the width is narrow just $100 \mathrm{~m} \sim 300 \mathrm{~m}$, the process of flood simulation also require that the calculation grid is smaller than the width of main channel, therefore, in this article we divide the Dahuangbao detention basin into 9800 grids, the length of grid is $50 \sim 80 \mathrm{~m}$. Mesh refinement improves its accuracy, it although sacrificed computing speed, but can be more accurately simulated hydraulic situations in the local area. The meshing of the model as shown in Figure 5.

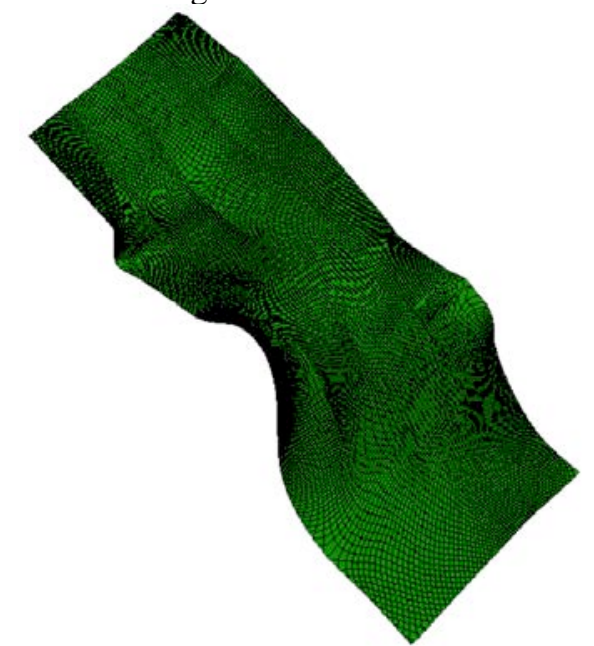

Fig.5. The grid partitioning in Dahuangbao detention basin

\section{4 calculation conditions}

1) design flood

According to the flood dispatching principle of north canal, the design flow of $2 \%$ frequency flood from north canal to Tumenlou is $1980 \mathrm{~m}^{3} / \mathrm{s}$, which vented by Qinglongwanjianhe $1680 \mathrm{~m}^{3} / \mathrm{s}$, discharge from Muchangzha to north canal $300 \mathrm{~m}^{3} / \mathrm{s}$. Qinglongwan jianhe discharge flood to Langerwo, it discharge $900 \mathrm{~m}^{3} / \mathrm{s}$ by river to Lizigu and then get into Chaobaixin river, the rest of flood is discharged from Langerwo inlet sluice to Dahuangbao detention basin.

2) Topography and roughness 
Topographic data using 1:10,000-topographic maps, Beijing 54 coordinate system, national 85 high elevations.

Roughness values refer to the project results of the establishment and application of yongdinghe flood-control system, it divide the land using information of detention basin into 9 categories: (1) road, embankment, dam; (2) fruit-bearing forest; (3) housing; (4) fish pond, reservoir; (5) paddy field, dry land, grassland; (6) land; (7) the riverbed; (8) reed; (9) Valley field, According to the analogy of types of underlying surface to determine the appropriate roughness value, the value range is $0.035 \sim 0.09$.

3) Characteristic points and control points

In order to analyze the diversion process and flood routing features of detention basin in detail, we set the typical characteristic points for the significant gate, pumping station, levee dam and demarcation point in scheme calculation. Chen Zhaozhuang is the only gauge flood control point, when the water level approach to $2.87 \mathrm{~m}$, it discharge to the next partition. Regard the flood diversion gate and water conservancy projects as the basis, determining the characteristic points of analysis of the results and the monitoring. Through the observation of water level process of feature point location, the discharge time and the data result of the gate using order to master the flood change of the whole detention basin.

There are 83 villages in Dahuangbao detention basin, For the convenience of analysis, in the calculation model we set up observation points in the administrative villages, the position of the measuring points are divided into zhuangtaishang andzhuangtaixia two parts. Zhuangtaishang represents the villages within the detention basin considering the design flood level and the high point of construction; zhuangtaixia represents the village point out of the safety board. Select 146 village monitoring sites in total, including 83 sites located in zhuangtaixia village and 63 sites located in zhuangtaishang village.

\section{Result analysis of different frequency flood routing after land subsided}

The calculation considers about two schemes in 20 years and 50 years in the condition of ground settlement. In this two schemes, the flood flows into Langerwo intake river from the Langerwo sluice gate along the intake river involving to downstream, when the water level exceeds the reserved intake gate or the height of embankment gap, it spreads to both sides. Because the evolution process of the flood before and after the ground settlement is basically the same and also by the limited space, the article below illustrates the flood evolution process after land subsidence in 20 years and 50 years, and then analyzes the influence of the ground settlement on the flood evolution comparing the flood evolution process before and after the land subsidence.

\section{1 analysis of the calculation result after land subsidence in 20 years}

In this scheme, the flood in intake river approaches to Chen Zhaozhuang River after $15 \mathrm{~h}$, the propagation velocity is $0.265 \mathrm{~m} / \mathrm{s}$. After water diffusion, because the area increases rapidly, the speed slowed down significantly, spread speed of most of points 
is less than $0.1 \mathrm{~m} / \mathrm{s}$. The water level of Chen Zhao village point rose up gradually, the stable water level is $2.498 \mathrm{~m}$, and it did not reach the conditions of the flood diversion control from partition I to partition II and III. So Dahuangbao detention basin just use the partition I in this scheme. With the time of diversion continuing, the flood storage volume and submerged area of Dahuangbao detention basin increased gradually, when the diversion finished, the biggest submerged area is $40.43 \mathrm{~km}^{2}$, the final storage volume is $0.0375336 \mathrm{~km}^{3}$,The maximum flood flow is $542 \mathrm{~m}^{3} / \mathrm{s}$, The highest level is $3.5 \mathrm{~m}$,Stable water level $2.51 \mathrm{~m}$. The highest level of Chenzhaozhuang is $2.498 \mathrm{~m}$, it did not reach the diversion condition to partition II .

\subsection{Analysis of the calculated results in50 years after the settlement}

In this scheme, the flood in intake river approaches to Chen Zhaozhuang automatic gate after $20 \mathrm{~h}$,The average head velocity $0.2 \mathrm{~m} / \mathrm{s}$, it shows that the water level of Chenzhaozhuang is up to $2.87 \mathrm{~m}$ after the diversion about 6 hours. According to the dispatch principle, when the water level of Chenzhaozhuang exceeds $2.87 \mathrm{~m}$, it needs to discharge flood to partition II, the calculated result shows that if it only uses partition I and partition II to mitigate flood and the water level of Chenzhaozhuang is still rising, should open the gate of partition III immediately, The highest water after stabilization is $2.90 \mathrm{~m}$. If it still exceeds the design water level, should mitigate flood to partition III, so we consider this scheme that open the gate of partition II andIII at the same time.

Therefore, in this scheme Dahuangbao detention basin uses partition I , II, III for detention. With the time of diversion continuing, the flood storage volume and submerged area of Dahuangbao detention basin increased gradually, when the diversion finished, the biggest submerged area of detention basin is $154.87 \mathrm{~km}^{2}$, the biggest storage volume of partition I , II ,IIIis respectively $0.07733 \mathrm{~km}^{3}, 0.01895 \mathrm{~km}^{3}$, $0.05698 \mathrm{~km}^{3}$, The total maximum flood flow is $0.10827 \mathrm{~m}^{3}$.

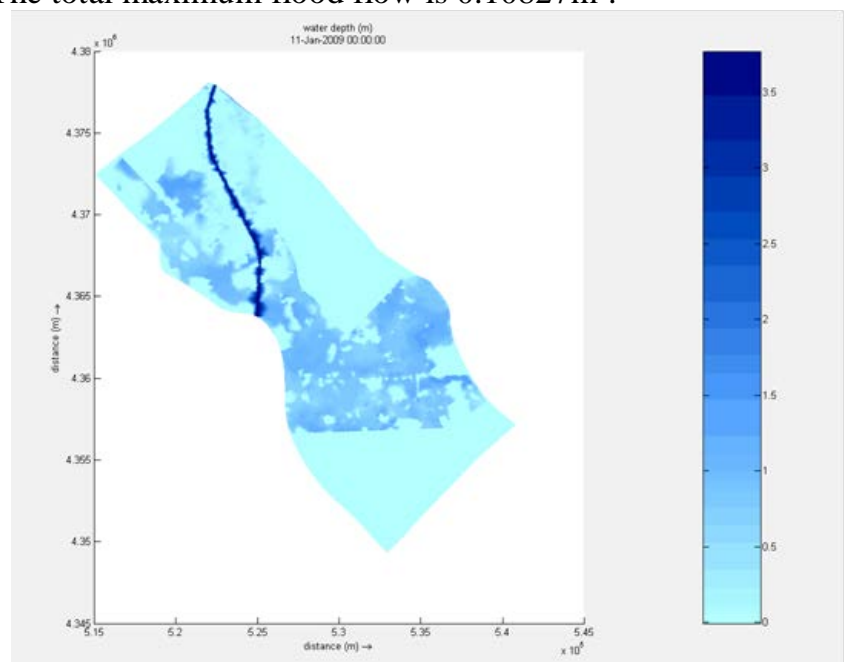

Fig.6. The water levels of main reference points in I zone with 50-year return period flood 


\subsection{Comparative analysis of the flood evolution before and after land subsidence}

The partition of Dahuangbao detention basin is obviously, therefore, when the research object is submerged water level; select a characteristic point to be representative in every partition. Chenzhaozhuang is located in partition I, when the water level reaches $2.87 \mathrm{~m}$, artificial levee breach discharge to next partition. In partiton II 、 III select the middle placed pumping station 6 and Gaozhuangzi. Analyze the influence of ground settlement of Dahuangbao detention basin on flood water level by comparing the submerged water level in flood evolution process of Chenzhaozhuang, pumping station 6 and Gaozhuangzi.

The analysis results show that: the ground subsidence affected the water level and the flood arrival time of characteristic points in submerged area obviously, when it suffers the flood in 50 years, the ground subsidence make that the flood approach to the first detention part Chenzhaozhuang 20min earlier and the submerged water level decreased $0.326 \mathrm{~m}$;but also make that the flood approaches to next detention part pumping station $617 \mathrm{~h}$ delayed and the submerged water level decreased $0.282 \mathrm{~m}$, make that the flood approaches to last detention part Gaozhuangzi 6h delayed and the submerged water level decreased $0.236 \mathrm{~m}$.

\subsection{Influence of land subsidence on the security in detention basin}

Only using partition I to mitigate flood when it meet the flood in 20 years; using partition I 、 II 、 III to mitigate flood when it meet the flood in 50 years, its flood diversion is 2.88 times than in 20years.

When the detention basin is working, according the diversion amount to launch every detention partition on after another. Before the land subsidence, the partition cofferdam can basically ensure that the partition storage the flood obey the dispatch principle. However, the elevation of current levee and cofferdam can not meet the requirement, Some will overflow before it reach the predetermined flood conditions. The cofferdam of partition I and III --Yandu Canal is the worst, its current elevation of $2.7 \mathrm{~m}$ is significantly lower than the design elevation, it can not achieve the partition application principle in the diversion application. therefore,we should consider the current elevation of Yandu canal embankment in the calculation, and redo the flood diversion routing. It shows that Yandu canal can not block the flood in 20 years after land subsidence, which caused that the flood get into some area of partition II, and the submerged area increased $6.05 \mathrm{~km}^{2}$, stable water level is $2.36 \mathrm{~m}$; when it suffers the flood in 50 years, because the cofferdam lower than the diversion water level, the flood get into partition II earlier, which make the biggest submerged area of partition I decreased. Because partition I, II and III are launched at the same time, the water level raised slowly, which make the biggest submerged area decreased $8 \mathrm{~km}^{2}$ than before the levee settlement. 


\section{5 summary}

To the agricultural areas which are used as detention basin, analyze the simulated results of the scheme of different frequency flood before and after the land subsidence by using the flood routing model based on ADI method, the following conclusions can be obtained:

1 ) analyzing the land subsidence value and the spatial distribution characteristics of land subsidence in Dahuangbao detention basin from 1985 to 2008 can obtain that the average cumulative settlement of detention basins is $288 \mathrm{~mm}$, the average settlement rate is $13 \mathrm{~mm} / \mathrm{a}$; the area which cumulative settlement between $0 \sim 500 \mathrm{~mm}$ is large of $251.8 \mathrm{~km}^{2}$, it occupied $87.1 \%$ of the whole settlement area, although it is at a relatively low level in Tianjin, it still has a big impact on the detention basin.

2) the influence of land subsidence on the water level of the characteristic points in submerged area and the flood arrival time is obvious. The basic law is that the flood arrival time in partition I is earlier, the submerged water level dropped a lot; the flood arrival time of partition II andIII is delayed. The submerged water level dropped less than partition I .

3) the simulation of flood routing model in detention basin shows that: when the levee and cofferdam suffer two frequency flood before land subsidence, it can meet the requirement of partition flood storage; after land subsidence, when it suffer the flood in 20 years, the detention basin only need to launch partition I , the stable water level is $2.51 \mathrm{~m}$, when it suffer the flood in 50 years, the detention basin need to launch partition I , II and III, the water level is $2.36 \mathrm{~m}$ when it store the flood stably. Due to the subsidence, the elevation of some levee and cofferdam in detention basin is badly lower than the design elevation even lower than the stable water level after diversion, which makes that the cofferdam cannot block the water effectively in partition application and also cause that the detention basin cannot store flood effectively by dispatch principle. It will affect the security of Dahuangbao directly.

\section{Acknowledgment}

Funds for this research were provided by science and technology funds from Tianjin Agricultural University（2014N05）.

\section{References}

1. Zhou Chaohong, Liu Bo, Gao Yunfeng.: Research on the Influence of Land Subsidence to Water Conservancy Engineering in Tianjin. J. Journal of Engineering Geology. 13(S1),135139 (2005) 
2. Gu Xiaorong, Liu Hongyan, Lu Mei.: Analysis on the Influence of Land subsidence in Tianjin to Haihe River Trunk Stream Flood Discharge Capacity. J. China Flood \& Drought Management, 24(01), 56-57+62(2014)

3. Caleffi Valerio, Valiani Alessandro, Zanni Andrea.: Finite Volume Method for Simulating Extreme Flood Events in Natural Channels. J. Journal of Hydraulic Research. 41(2), 47-55 (2003).

4. Liu Shukun, Li Shigong.: Flood Routing Numerical Simulation on Xiaoqinghe Flood Diversion Area. J. Advances In Water Science. 2(3), 188-192(1991)

5. Zhou Xiaode, Chen Huijun, Shen Jin.: 2D Flood Routing and Flood Risk Analysis on Flood Detention Zone. J. Journal of Xi'an University of Technology. 12(3), 244-250(1996)

6. CAO Zhifang, LI Yitian.: Two-Dimensional Flood Routing Numerical Simulation on Flood Storage and Detention Area. J. Journal of Basic Science and Engineering. 9(3), 74-79(2001)

7. LI Da-ming, LIN Yi.: Mathematical Model of River and Flood Retention Areas. J. Journal of Tianjin University. 42(1), 47-55 (2009)

8. Hu, R L, Yue, Z Q, Wang, L C.: Review on Current Status and Challenging Issues of Land Subsidence in China. J. Engineering Geology, 76(l-2), 65-77(2004)

9. Wang Ruobai, Sun Dongping.: Land Subsidence in Tianjin Region and its Influence on the Geographical Environment. J. ACTA GEOGRAPHICA SINICA. 49(4): 317-323(1994)

10. Dong Ke-gang, Wang Wei, Yu Qiang ,Lu Yang.: Research on Land Subsidence Prevention and Control History in Tianjin. J. The Chinese Journal of Geological Hazard and Control, 03, 54-59(2008) 